\title{
EFFECT OF DIETARY PROPOLIS SUPPLEMENTATION IMMUNOCOMPETENCE PARAMETERS OF COBB BROILER CHICKS
}

\author{
A.M. Abdelsalam ${ }^{1}$, A.M . Abd ElAzim² ${ }^{2}$ A.M.R. Othman ${ }^{1}$, A. Makram² and E.M. Omar ${ }^{2}$ \\ 1: Poultry Nutrition, Animal Production. Institute, Agriculture. Research Center. \\ 2: Poultry Production Department, Faculty of Agriculture, Fayoum University, Egypt \\ Corresponding author: Adel Abdelsalam.E-mail adelsalam1@gmail.com
}

\section{SUMMARY}

$\mathrm{T}$ his experiment was carried out at El-Takamoly Poultry Project. The objective of this study was to evaluate the effect of dietary propolis supplementation on immune response of broiler chicks. A total number of 200 unsexed one day-old Cobb broiler chicks were used in this experiment. They were divided into five groups, with four replicates of ten chicks each. Chicks were fed a starter diet without propolis supplementation during the first 6 days of age. At the 7 th day, birds were fed diets containing different levels of propolis $(0,200,400,600$ and $800 \mathrm{mg} / \mathrm{kg})$ till the end of 6 th weeks of age. Ethanolic extract of propolis was added to mixed diets. The result revealed that the mortality rate was within the normal range and not related to treatments studied.. Concerning to Cell-mediated immunity the chicks fed diet added 400, 600 and $800 \mathrm{mg}$ propolis/kg diet had significantly highr response to PHA-P injection compared to control-fed group. The Heterophils / lymphocytes ratio $(\mathrm{H} / \mathrm{L})$ decreased with increased the level of dietary propolis in the diets. Generally, it can be concluded that chicks fed diet added 600 and $800 \mathrm{mg}$ propolis/kg diet had significantly improvement in immune response and some blood parameters.

Keywords; Propolis, broiler chicks' nutrition, Immunocompetence, Hemasatological.

\section{INTRODUCTION}

In the last decade, Interest in using immunomodulators to improve cellular and humoral immune functions and resistance against infections in chickens and other domestic animals has increased. One of the increasingly important recent natural products that have been found to modulate immune functions and growth promoting, is propolis. (Ziaran et al., 2005 and Abdelsalam et al., 2018). Takasi et al. (1994) stated that propolis inhibits bacterial growth by preventing cell division, thus resulting in the formation of pseudomulticellular streptococci. In addition, propolis disorganized the cytoplasm, the cytoplasmic membrane and the cell wall, caused a partial bacteriolysis and inhibited protein synthesis. Hegazi et al. (1995) studied the effect of some bee products on immune response of chicken infected with virulent NDV. They found that, the mortality rate was reduced in-groups infected with virulent NDV and subsequently treated either with propolis or honey if compared with the infected groups only. Valdes et al. (1985) stated that alcoholic extracts of propolis inhibited the growth of various bacteria. Takasi et al. (1994) stated that propolis inhibits bacterial growth by preventing cell division, thus resulting in the formation of pseudo-multicellular streptococci. Many researchers had investigated the antibacterial activity of propolis and its extracts against Gram-positive and Gram-negative strains and found that propolis had antibacterial activity against a wide range of Gram-positive rods but had a limited activity against Gram-negative bacilli. Thus, the objective of the present study was to evaluate the effect of extracted propolis on immune response of the broilers.

\section{MATERIALS AND METHODS}

The experimental work of the present study was carried out at El-Takamoly Poultry project, Fayoum Governorate. A total number of 200 of unsexed one day-old Cobb broiler chicks were used in this experiment; the chicks were grown in floor brooder and were fed on experimental diet without propolis supplementation for one week of age. They were fed a starter diet without propolis supplementation during 
the first week, at the $7^{\text {th }}$ day of age, birds were fed diets containing different levels of propolis $(0,200,400$, 600 and $800 \mathrm{mg} / \mathrm{kg}$ ) till the end of $6^{\text {th }}$ weeks of age. Ethanolic extract of propolis was added to mixed diets.

\section{Parameters tested}

\section{Mortality rate:}

Accumulative mortality rate was obtained by collection the number of dead birds during the experiment and divided it on the initial number of chicks at the beginning of experiment.

\section{Immunocompetence measurements:}

\section{Cell-mediated immunity}

Response induced in vivo by mutagens was evaluated by injection of phytohemagglutinin-P (PHA-P) into the web between the second and the third digits of chicks. Eight chicks from each group, at 39 days of age were used. Each chick was intradermally injected in the toe web of the left foot with $5 \mu \mathrm{g}$ phytohemagglutinin-P (Sigma Chemical Co., St. Louis, MO 63178) in $0.1 \mathrm{ml}$ of sterile saline measured with micrometer before injection and at 24, 48 and $72 \mathrm{hr}$ after PHA-P injection. The toe web swelling was calculated as the difference between the thickness of the toe web before and after injection.

\section{Relative lymphoid organs weight}

After completion of PHA-P, the chicks were weighed and slaughtered (after 8 hours of fasting). The bursa of Fabricius, spleen and thymus (all lobes from left side of the neck) were removed and weighed to the nearest milligram. Their relative weights were expressed as percentage of live fasted body weight.

\section{Heterophils / Lymphocytes ratio}

At 42 day of age, blood samples were obtained from each group for heterophils (H) and lymphocyte (L) enumeration based on the procedures of Gross and Siegel (1983). Briefly, one drop of blood being smeared on each of glass slides. The smears were stained using Wrights stain. Three hundred leukocytes, including granular (heterophils) and non granular (lymphocyte) ratio were calculated.

\section{Statistical analysis:}

Data were analyzed using general linear model procedure of SPSS software SPSS, (1999). Significant differences among treatment means were determined using Duncan's multiple range test Duncan, (1955) According to the following model:

$$
Y_{i j}=\mu+T_{i}+e_{i j}
$$

Where: $\mu=$ Overall means, $\mathrm{T}_{\mathrm{i}}=$ Treatment effect $(\mathrm{i}=1-5), \mathrm{e}_{\mathrm{ij}}=$ Experimental error.

\section{RESULTS AND DISCUSSION}

\section{Mortality rate:}

The calculated cumulative mortality $\%$ of chicks during the period from 7-42 days of age is presented in Table (1). The results indicated that the percentage of mortality was $2.5 \%$ in chicks fed diet containing $0,200,400$ and $800 \mathrm{mg}$ propolis and was 5\% in the chicks fed diet containing $600 \mathrm{mg}$ propolis. However, it appears that mortality rate was within the normal range and not related to treatments studied.

Table (1): Mortality rate \% of birds fed different levels of propolis supplementation.

\begin{tabular}{lccccc}
\hline Treatments & \multicolumn{5}{c}{ Propolis (mg/kg diet ) } \\
\hline Item & 0 & 200 & 400 & 600 & 800 \\
Total number of chicks at the & 40 & 40 & 40 & 40 & 40 \\
beginning of exp. & 1 & 1 & 1 & 2 & 1 \\
Number of dead birds & 2.5 & 2.5 & 2.5 & 5 & 2.5 \\
Mortality \% & & & 5 & \\
\hline
\end{tabular}




\section{Cell-mediated immunity (CMI):}

Cell-mediated immune response as measured by PHA stimulation (Toe) is presented in table (4). It could be noticed that the chicks fed diet with added 400, 600 and $800 \mathrm{mg}$ propolis/kg diet had significantly $(\mathrm{P} \leq 0.01)$ hyper responder to PHA-P injection compared to control-fed group. Propolis according to research has shown to be effective against a variety of bacteria, viruses, fungi and molds. It has been shown to be a non-specific immunostimulant. The delayed hypersensitivity skin test using propolis as sensitizing antigen showed specific stimulation to propolis after 72 hours after inoculation with specific antigen. The PHA intradermally reaction, a T-Iymphocyte-dependent response, has been well researched and has been shown to be a reliable indicator of in vivo cellular immunity in poultry (Goto et al., 1978 and McCorkle et al., 1980). The skin response reflects a complex series of physiological events such as mitogen-receptor and lymphocyte-macrophage interactions, release of chemical mediators, cellular proliferation and changes in vascularity (Chandra and Newberne, 1977). Egyptian propolis gave the typical delayed hypersensitivity when inoculated to the sensitized chickens. The thickness index was $0.90 \mathrm{~mm}$ thickness if compared with nonsensitized control group $0.12 \mathrm{~mm}$ thickness (Hegazi et al., 1996).

Table (2): Toe-web swelling (difference) of birds fed different levels of propolis supplementation.

\begin{tabular}{|c|c|c|c|c|c|c|}
\hline \multirow{2}{*}{$\begin{array}{l}\text { Time (hrs) post } \\
\text { PHA-P injection }\end{array}$} & \multicolumn{5}{|c|}{ Propolis (mg/kg diet ) } & \multirow{2}{*}{ SE } \\
\hline & 0 & 200 & 400 & 600 & 800 & \\
\hline 24 & $0.11^{\mathrm{B}}$ & $0.15^{\mathrm{B}}$ & $0.23^{\mathrm{AB}}$ & $0.34^{\mathrm{A}}$ & $0.31^{\mathrm{A}}$ & 0.02 \\
\hline 48 & $0.05^{\mathrm{C}}$ & $0.07^{\mathrm{BC}}$ & $0.13^{\mathrm{AB}}$ & $0.18^{\mathrm{A}}$ & $0.17^{\mathrm{A}}$ & 0.02 \\
\hline 72 & $0.03^{\mathrm{B}}$ & $0.03^{\mathrm{B}}$ & $0.08^{\mathrm{AB}}$ & $0.12^{\mathrm{A}}$ & $0.12^{\mathrm{A}}$ & 0.02 \\
\hline
\end{tabular}

$\overline{A, \ldots C}$ values in the same row within the same item followed by different superscripts are significantly different (at $P \leq$ 0.01 for $A$ to $C$ ).

\section{Relative lymphoid organs weight:}

The present results indicated that there was no significant effect of propolis on relative weight of bursa, or spleen (Table5). Grossly the lymphoid organs appeared normal. In the absence of well developed lymph node system in the chicken, the spleen is the major organ involved in immune response to some antigens. With respect to relative thymus weight, the results revealed that the chicks fed diet added 600 and $800 \mathrm{mg}$ propolis/kg diet had significantly higher $(\mathrm{P} \leq 0.01)$ relative thymus weight compared to control group. But there was no significant difference between control and $200 \mathrm{mg}$ propolis diet. The immunological function of thymus is to provide a specific environment essential for T-cells differentiation, which is essential for cell-mediated immunity and modulation of immune response (Owen, 1977). The previous results suggest that the size of lymphoid organs weight may not be associated with higher immune response of chickens. A similar result was observed by Fathi et al. (2003) they reported that size of bursa and thymus did not affect the cell mediated immune response.

Table (3): Relative lymphoid organs (Means \pm SE) of birds fed different levels of propolis supplementations

\begin{tabular}{ccccccc}
\hline \multirow{2}{*}{ Item } & \multicolumn{5}{c}{ Propolis $(\mathrm{mg} / \mathrm{kg}$ diet $)$} & \multirow{2}{*}{ SE } \\
\cline { 2 - 6 } & 0 & 200 & 400 & 600 & 800 & 0.01 \\
Bursa, \% & 0.08 & 0.06 & 0.08 & 0.07 & 0.06 & 0.02 \\
Spleen, \% & 0.15 & 0.16 & 0.16 & 0.18 & 0.20 & $0.21^{\mathrm{A}}$ \\
Thymus, \% & $0.18^{\mathrm{C}}$ & $0.18^{\mathrm{C}}$ & $0.20^{\mathrm{B}}$ & $0.21^{\mathrm{A}}$ & 0.002 \\
\hline
\end{tabular}

$A, \ldots C$ values in the same row within the same item followed by different superscripts are significantly different (at $P \leq$ 0.01 for $A$ to $C$ ). 


\section{Abdelsalam et al.}

\section{Heterophils / lymphocytes ratio:}

White blood cells differential count for broiler chicks fed different levels of propolis are presented in table (6). It could be noticed that there was no significant difference between control and low level of propolis supplementation for both heterophils and lymphocytes count. Conversely, the medium and high level of propolis supplementation significantly decreased $(\mathrm{P} \leq 0.01)$ the heterophils count and increased $(\mathrm{P} \leq 0.05)$ the lymphocytes count when compared with the control-group. In accordance to $\mathrm{H} / \mathrm{L}$ ratio, our results showed that the propolis supplementation at 400, 600 and $800 \mathrm{mg} / \mathrm{kg}$ diet significantly $(\mathrm{P} \leq 0.01)$ decreased the $\mathrm{H} / \mathrm{L}$ ratio of birds. The $\mathrm{H} / \mathrm{L}$ ratio is a recognized measure of stress in birds (Davison et al., 1983; Gross and Siegel, 1983 and Maxwell, 1993) that has become a valuable tool in stress research especially when combined with the convenience and repeatability of automated blood cell counts.

Table (4): Heterophils and lymphocytes count of birds fed different levels of propolis supplementations

\begin{tabular}{|c|c|c|c|c|c|c|}
\hline \multirow{2}{*}{ Item } & \multicolumn{5}{|c|}{ Propolis (mg/kg diet ) } & \multirow{2}{*}{$\mathrm{SE}$} \\
\hline & 0 & 200 & 400 & 600 & 800 & \\
\hline Heterophils & $25.25^{\mathrm{A}}$ & $24.75^{\mathrm{A}}$ & $21.75^{\mathrm{B}}$ & $20.25^{\mathrm{B}}$ & $19.00^{\mathrm{B}}$ & 0.98 \\
\hline Lymphocytes & $64.75^{\mathrm{b}}$ & $65.25^{\mathrm{b}}$ & $67.75^{\mathrm{ab}}$ & $69.75^{\mathrm{a}}$ & $70.00^{\mathrm{a}}$ & 1.12 \\
\hline H/ L ratio & $0.39^{\mathrm{A}}$ & $0.32^{\mathrm{A}}$ & $0.32^{\mathrm{B}}$ & $0.29^{\mathrm{B}}$ & $0.27^{\mathrm{B}}$ & 0.02 \\
\hline
\end{tabular}

\section{CONCLUSION}

In conclusion our results confirm that there was significant effect of propolis on some immunological parameters. The results revealed that chicks fed diet added 600 and $800 \mathrm{mg}$ propolis $/ \mathrm{kg}$ diet had significantly improvement in immune response and some blood parameters.

\section{REFERENCE}

Abdelsalam, A.M., A.M. Abd El-Azzim. A.M.R. Othman, A. Makram and E.M. Omar. 2018. Effect of Dietary Propolis Supplementation on Growth Performance of Cobb Broiler Chicks. The 10th International Poultry Conference (Poster) from 26-29 November(2018). Sharm Elsheikh., Cairo, Egypt. 43-51.

Chandra, R.K. and Newberne, P.M. (1977). Nutrition, immunity and infections. Plenum Press, New York.

Davison, T. F.; Rowell, L.G. and Rea, J. (1983). Effects of dietary corticosterone on peripheral blood lymphocyte and granulocytes populations in immature domestic fowl. Res. Vet. Sci., 34: 236-239.

Duncan, D. B. (1955). Multiple range and multiple F-test. Biometrics, 11: 1-42.

Fathi, M. M.; Ali, R.A. and Qureshi, M.A. (2003). Comparison of immune responses of inducible nitric oxide synthase (INOS) hyper-and hypo responsive genotypes of chickens. Int. J. Poult. Sci., 2: 280-286.

Goto, N.; Kodama, H.; Okada K. and Fujimoto, Y. (1978). Suppression of phytohemagglutinin skin response in thymoectomized chicken. Poult. Sci., 57: 246-250.

Gross, W.B. and Siegel, P.B. (1983). Evaluation of the heterophil/lymphocyte ratio as a measure of stress in chickens. Avian Dis. 27: 972-979.

Hegazi A. G.; El Miniawy H. F. and El Miniawy F. A. (1995). Effect of some honeybee products on immune response of chicken infected with Virulent NDV. Egyptian J. Immuol. 2 (2): 79-86.

Hegazi, A. G.; El Miniawy F.A and Abd El Hady, F. K. (1996). Influence of adminstration of propolis on chicken imunne status. The Egypt. J. of Immunal. 3(1): 111- 116. 
Maxwell, M.H. (1993). Avian blood leukocyte responses to stress. World's Poult. Sci. Journal, 49:34-43.

McCorkle, F.; Olah, I.; and Glick, B. (1980). The morphology of the phytohemagglutinin-induced cell response in the chicken's wattle. Poult. Sci., 59: 616-623.

Owen, J.J.T., (1977). Ontogenesis of Lymphocytes. In: B and T all in immune recognition. John wile and Sons. New York, pp: 21-34.

SPSS, For Windows (1999). User Guide: Statistics. Version 10. SPSS Inc. Chicago, IL, USA.

Takasi, Kikuni NB and Schilr H. (1994). Electron microscopic and microcalorimetric investigations of the possible mechanism of the antibacterial action of propolis. Povenance planta Med., 60(3): 222-227.

Valdes, G.; Rojas, H., N.M. and Morales Vera, C. (1985). Comparative study of the antimicrobial activity of propolis and that of antibiotics and conventional disinfectants. Ciencia Y Tenica en la Agriculura, Apiculura 1, 23-36

Ziaran, H. R., Rahmani, H. R. and Poureza, J. (2005). Effect of dietary oil extract of propolis on immune response and broiler performance. Pak. J. Biol. Sci., 8 (10):1485-1490.

\section{تأثير إضافة البروبليس علي المقاييس المناعية في سلالة دجاج الكب}

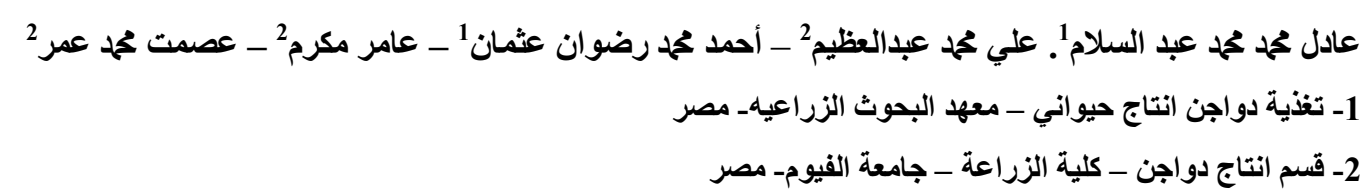

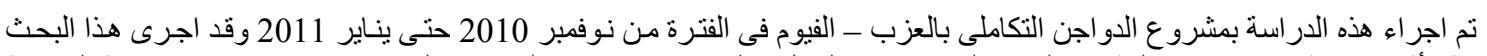

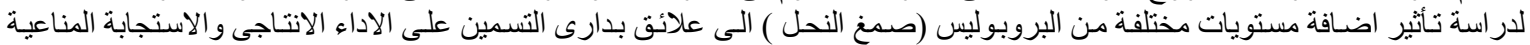

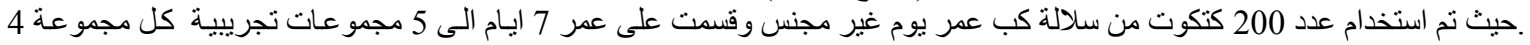

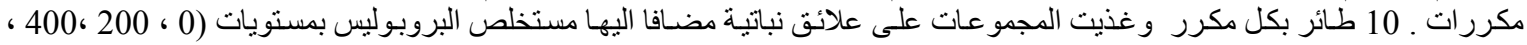

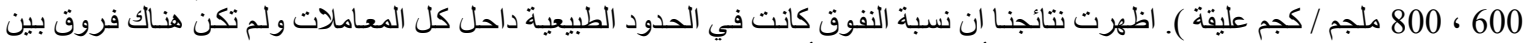

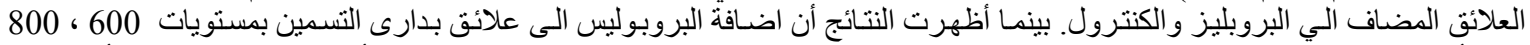

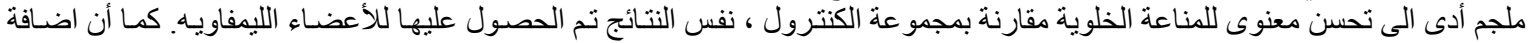

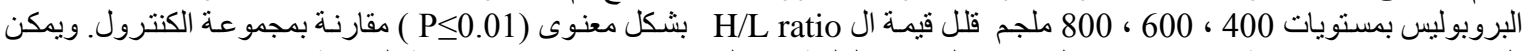
تلخيص ان وجد ان اضافة 600 او 800 ملجم بروبوليس في العليقة ادى الى تحسن معنوى في الاستجابة المناعية .

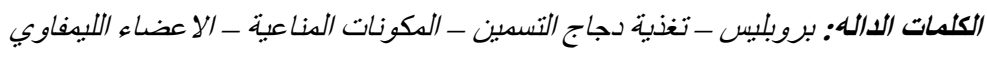

